\title{
The Human Right to Water and its Application in the Occupied
}

Palestinian Territories

Amanda Cahill Ripley

University of Lancaster, UK

The Human Right to Water and Its Application in the Occupied Palestinian Territories provides an overview and examination of the human right to water as determined under international human rights law, including establishing its current legal status and substantive content and dealing with general questions and issues related to economic, social and cultural rights which affect the right to water.

This book provides an overview and examination of the human right to water as determined under international human rights law. This is a highly topical issue, with the UN General Assembly having passed a resolution which declares access to clean water and sanitation a human right (New York, Jul 28 2010), the recent appointment of the UN Independent Expert on the issue of human rights obligations related to access to safe drinking water and sanitation, and movement within the NGO community for an international water treaty. Amanda Cahill Ripley analyses the current legal status, substantive content, and obligations correlative to the right, and examines the relationship between other economic, social and cultural rights related to the right to water.

The book goes on to look more specifically at the application of the human right to water in the Occupied Palestinian Territories. Using innovative methodology, Cahill Ripley combines legal analysis with a qualitative social science empirical case study to explore the enjoyment of the right 'on the ground'. The wider implications of the case study findings are then considered, looking at what can be done to strengthen the right legally in terms of its status and codification, and what remedy can be found for violations of the right, both specifically in the Occupied Palestinian Territories and in a more general context.

Visit http://www.routledge.com/books/details/9780415577861/ for more details.

\section{Contents:}

1. The Historical Legal and Political Context of the Right to Water 2. The Human Right to Water - Legal Status and Normative Content 3. Obligations Correlative to the Right to Water 4. The Right to Water in the Occupied Palestinian Territories (West Bank)

Part I: International Legal Sources 5. The Right to Water in the Occupied Palestinian Territories (West Bank) Part II: Bilateral and Domestic Legal Sources 6. The Right to Water in the Occupied Palestinian Territories (West Bank)

Part III: A Case Study in the Southern West Bank 7. Where do we go from here? Conclusions and Recommendations for developing the Right to Water

\section{Routledge Taylor \& Francis Group}

For more details, or to request a copy for review, please contact:

Alexandra Fryer, Marketing Coordinator Alexandra.Fryer@tandf.co.uk
+44 (0) 2070176746 


\section{0\% Discount Order Form}

\section{UK \& ROW ORDERS}

P Tel: 01235400524

Eax: 02070176699

○ Email: book.orders@routledge.co.uk

$\Xi$ Post: David Armstrong, Taylor and Francis FREEPOST

200 Milton Park, Abingdon Oxon OX14 4TA

\section{US ORDERS}

Tel: Toll Free: $800-634-7064$

E Fax: $800-248-4724$

7 Email: cserve@routledge-ny.com

$\Xi$ Post: Taylor \& Francis Books

Dept: Textbook Customer Service

7625 Empire Drive, Florence, KY 41042

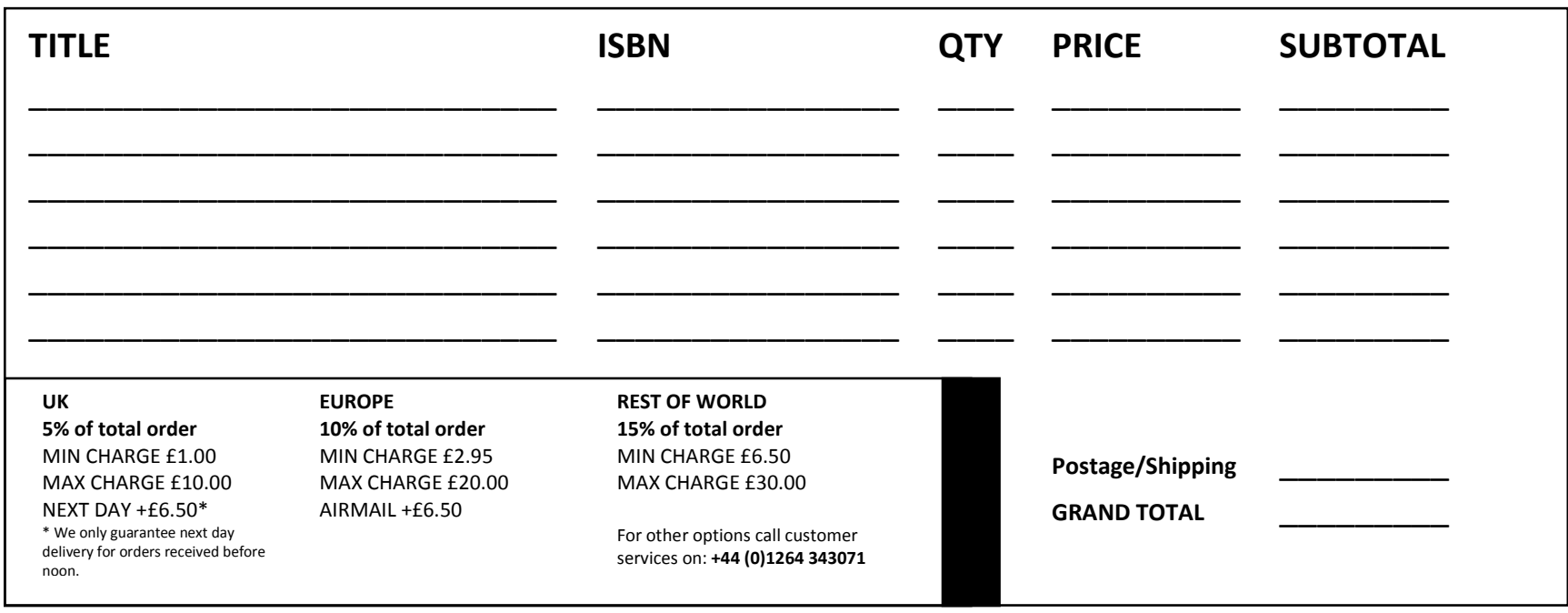

\section{ADDRESS DETAILS}

SURNAME

DEPARTMENT

ADDRESS

COUNTY

COUNTRY

TELEPHONE

EMAIL

VAT NUMBER (EU MEMBER STATES ONLY)
FIRST NAME

INSTITUTION

TOWN

POST/ZIP CODE

FAX NUMBER

SELECT PAYMENT METHOD (please tick or fill appropriate boxes \& select card type)
$\square$ Cheque payable to Taylor \& Francis $f$
$\square$
$\square$ Please send me a pre-payment invoice
Credit Card No (no spaces)
(my ref number)

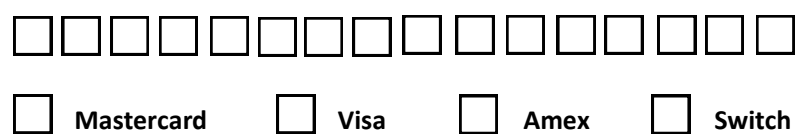
EXPIRY DATE $\square \square / \square \square$ Month/year
Issue Number $\square \square$ (only applies to Switch)

\section{Routledge}

Taylor \& Francis Group
For more details, or to request a copy for review, please contact:

David Armstrong, Senior Marketing Executive David.Armstrong@tandf.co.uk 